\title{
Forecasting the Amount of Cash in Circulation Based on a Regression Model with Lagged Variables
}

\author{
MARINA BATOVA \\ Department of informatics and Management \\ Military University of the Ministry of Defense of the Russian Federation \\ Moscow, 14 Bolshaya Sadovaya st. \\ RUSSIA (MOSCOW)
}

\begin{abstract}
Despite the rather positive dynamics in developing the non-cash payment infrastructure, cash in Russia has been and remains the widespread instrument of payment. The purpose of this paper is the development of a model for forecasting the amount of cash in circulation in the country, namely the value of the monetary aggregate M0, by the example of the Russian Federation. At the same time, the objectives were set so that the resulting

model should be suitable for a sufficiently accurate rapid estimation of M0 value, should be easy to use, and should not be overloaded with many variables. The author succeeded in achieving these purposes in the research using a formal approach based on a model with lagged variables, autoregression and time series analysis, also using numerical methods. The lagged variables used were the inflation rate and the value of the monetary aggregate for a previous period. The high quality, accuracy and forecasting power of the model are substantiated. The average approximation error of the model did not exceed 5\%.Testing of the model using statistical data of the current year showed high accuracy of forecasting. Statistical data of official sources of the Russian Federation were used for the model development.

Key Words: cash in circulation, monetary aggregate M0, econometric modelling, inflation, forecasting.
\end{abstract}

Received: August 8, 2020. Revised: November 30, 2020. Accepted: December 17, 2020. Published: December 27, 2020.

\section{Introduction}

To date, a lot of research has been carried out on money circulation and money stock in various countries, including Russia. But this issue is still relevant.

The demand for money remains a topic of interest for researchers for more than 60 years [8].

In the paper [8], a detailed analysis of the problem is given and the evolution of economic views on the concept of demand for money is traced; the results achieved by the authors and other researchers in other countries on this problem are given; an overview of theoretical and empirical approaches to the modelling of the money stock both in Russia, and in other countries is given.

In the paper [27], the role of money in the monetary policy of the Bank of Russia, the development of monetary policy, the types of monetary aggregates in Russia, their measurement and evolution are studied in detail; the models of demand for money are considered.

The objectives of research on money circulation are different: the study of deep structural links in the country's economy; relations between macroeconomic indicators and monetary aggregates; identification of significant factors influencing the volume of money stock; search and modelling of an instrument of influence on the amount of supply; forecasting for financial, trading and exchange operations, etc.

The applied research methods are also diverse, although the predominance of statistical and econometric methods can be noted.

As for Russia, part of the research on Russian data relies on statistics made before the 1998 crisis, but the bulk of the papers is devoted to the analysis of data since 2000 , which refer to a period of relative economic stability after structural shifts in the country's economy in the late 1990s. At the same time, the changes taking place in the monetary sphere of Russia in recent years, as well as the change in the monetary policy regime pursued by the Bank of Russia, raise the question of the need to further study the demand for money in Russia, as well as the factors influencing the demand for monetary aggregates. [8]. 


\section{Problem Formulation}

\subsection{Money stock and monetary aggregates}

The money stock, or money supply, is defined as the aggregate of cash in circulation and non-cash resources in accounts held by individuals, legal entities, and by the state. [24].

Monetary aggregates are indicators of the structure of the money stock (money supply), types of money and monetary funds that differ from each other in the degree of liquidity, that is, the ability to quickly convert them into cash. Different countries use different methods to define monetary aggregates. In most countries, they are classified according to international terminology into M0, M1, M2 and M3.

In Russia, the Central Bank calculates three aggregates: M0, M1 and M2.

M0 includes only cash (banknotes, coins, piece of money) in national currency being in circulation outside the banking system.

$\mathrm{M} 1$ includes the aggregate $\mathrm{M} 0$ and the balances in national currency on settlement accounts, current accounts and other accounts on demand of the population, non-financial and financial organizations (except for the credit ones) that are residents of the Russian Federation.

Indicator M2 includes aggregate M1, as well as balances in national currency on fixed-term deposits and other funds raised for a term and belonging to the population, non-financial and financial organizations (except for the credit ones) that are residents of the Russian Federation.

Monetary aggregates reflect real economic processes and trends. They are used to estimate the level of provision of the economy with funds, characterize the level of sales of goods, as well as non-commodity payments and settlements in the country's economy.

\subsection{Research purpose and objectives}

Most of the studies, including the author's studies in one of her papers [6], focus on the monetary aggregate M2. This is quite natural, since it contains the largest amount of information about money circulation in the country and is the main ratio of cash and non-cash money. Researchers pay less attention to other monetary aggregates.

However, the monetary aggregate M0 is of no less interest for modelling, as it is the most liquid part of the money stock available for immediate use as a means of payment.

Despite the rather positive dynamics in developing the non-cash payment infrastructure, cash in Russia has been and remains the preferred instrument of payment, with an annual increase in the amount of circulation of both banknotes and coins. [28].
Forecasting and estimating the value of the monetary aggregate $\mathrm{M} 0$ and its comparison with other monetary aggregates gives insight into the amount of funds held by the population in the banking system. For example, whether this money is kept by the population "in their hands", or generate income from making deposits and thereby provides funds for issuing loans or investing, etc. There are many other more complex relations and interdependencies.

Thus, the actual purpose of this research was the development of a model for forecasting the amount of cash in circulation in the country, namely, the value of the monetary aggregate M0 using the example of the Russian Federation.

The main objectives of this research were to make the model suitable for rapid estimation of the M0 value, having sufficient forecasting power (the average forecast error would not exceed 5\%); at the same time, the model should be simple and practical to use, not overloaded with many variables, and be easily understandable even for non-specialists in econometrics.

\section{Problem Solution}

\subsection{Methods and approaches}

The main research methods were quantitative methods of statistics and econometrics, as well as methods for analyzing economic data [21].

It should be noted that the study of meaningful structural economic relations is not the subject of this paper. This research pursues a different purpose, namely: to obtain a working operational model that is suitable for forecasting the target variable M0. Therefore, the use of a formal approach based on time series analysis $[9,13,23]$, multiple regression [13, 25], techniques and forecasting of nonlinear dynamics [30], modelling with the use of autoregression and lagged variables [5, 13], as well as using numerical methods [15], was justified and expedient.

It often turns out that a formal approach gives better forecasts for economic and financial data, than forecasts based on calculations using meaningful macroeconomic models. [22].

\subsection{Variables of the model for forecasting}

A relationship between money circulation and price level is established, in one form or another, in classical papers on the quantitative theory of money $[14,17,18,20,26]$ and in modern works $[5,8,10$, 
$12,19,27,29,31,33]$. The papers [3, 32] also provide an overview and analysis of studies of this issue by the example of Asian, African and other countries.

Researchers include money circulation in the model in the form of demand for money, money stock, various monetary aggregates (for example, M0, but more often M1 and M2). The price level is included in the model in the form of price indices, deflators, inflation rate or index. When considering time series data, the relationship is established using the same time period. However, in some papers a lagged structure of money circulation and price level is noted [11].

An analysis of the scientific papers researching this issue, as well as the author's observations, suggest a lagged dependence of the target monetary aggregate M0 and the inflation rate in Russia; it can be argued that this dependence is negative.

Indeed, the increase in the inflation rate in the previous period $(t-1)$ causes fears and/or expectations of the depreciation of cash in society. Thus, it induces the tendency of people in the current period $t$ and in subsequent periods of time to get rid of cash (banknotes, coins), invest money in other assets (goods, movable and immovable assets, precious metals, stocks, etc.). The value of the monetary aggregate M0 decreases, and vice versa, consequently.

Thus, it is advisable to include the inflation rate indicator Inf (\%) in the developed model as an independent variable.

To improve the accuracy and forecasting power of the model, it is necessary to consider adding another variable to the model. The starting point was the consideration that often the current or future values of economic and financial variables are influenced by their previous quantities. Thus, it is advisable to add to the model a variable consisting of the values of the monetary aggregate $\mathrm{M} 0$ under study, but with a time lag.

Then we introduce the following notations for the variables of the model:

$M 0_{t}$ - Dependent variable for the value of the monetary aggregate $\mathrm{M} 0$ in the current (or forecast) period;

$\operatorname{Inf} f_{(t-k)}$ - Independent variable for the inflation rate $\operatorname{Inf}(\%)$ in the period $(t-k)$;

$M 0_{(t-k)}$ - Independent variable for the value of the monetary aggregate $\mathrm{M} 0$ in the period $(t-k)$, i.e. autoregressive variable with the lag $k$;

$k$-Time lag.

Further, it is necessary to establish the value of the lag $k$; investigate the form and strength of the dependence of $M 0_{t}$ on the variables of inflation rate $\operatorname{Inf} f_{(t-k)}$ and $M 0_{(t-k)}$; establish the type of the model expressing the influence of $\operatorname{Inf}(t-k)$ and $M 0_{(t-k)}$ on $M 0_{t}$. Then it is necessary to identify the model, i.e. to estimate its parameters using statistical data.

\subsection{Statistical data. Sample}

Statistical data of official Russian sources were used to specify and identify the model [7].

The source of statistical data on the inflation rate $\operatorname{Inf}(\%)$ is the Federal State Statistics Service of the Ministry of Economic Development of the Russian Federation (Rosstat) with its website gks.ru. The monthly data on the inflation rate are presented by Rosstat in the Unified Interdepartmental Information and Statistical System (EMISS). Access to EMISS is open to users at fedstat.ru. A set of statistical data on the inflation rate by months was used in relation to the corresponding month of the previous year.

The source of statistical data on the monetary aggregate M0 is the Central Bank of the Russian Federation, website crb.ru. The section "Statistics" provides open access to monthly statistical information on the money stock (structure, size, volumes of monetary aggregates M0, M1, M2 in national currency, billion roubles).

For this research and the construction of the model, a sample covering official statistical data by months for a 21-year period: from January 1999 to December 2019, was used by the author. Thus, the total sample size was 252 observations [7].

\subsection{Descriptive statistics}

The monetary aggregate M0 of 1999-2019 years has a generally increasing trend. During the period under review, the maximum value of the monetary aggregate M0 amounted to 9658.4 billion roubles in December 2019 (the observation number is 252); the minimum value was 174 billion roubles in March 1999 (the observation number is 3). (See Figure 1). The average value of M0 for the samples was 4133.14 billion roubles; the standard deviation was 2959.74 billion roubles; the median was 3793.95 billion roubles.

The inflation rate variable Inf (\%) of 1999-2019 years has a generally decreasing trend. The inflation rate in the period under review took the maximum value of $126.51 \%$ in July 1999 (the observation number is 7), and the minimum value of $2.2 \%$ in February 2018 (the observation number is 230). (See Figure 2). The average inflation rate for the sample was $14.35 \%$; the standard deviation was 19.49 percentage points; the median was $9.73 \%$. 


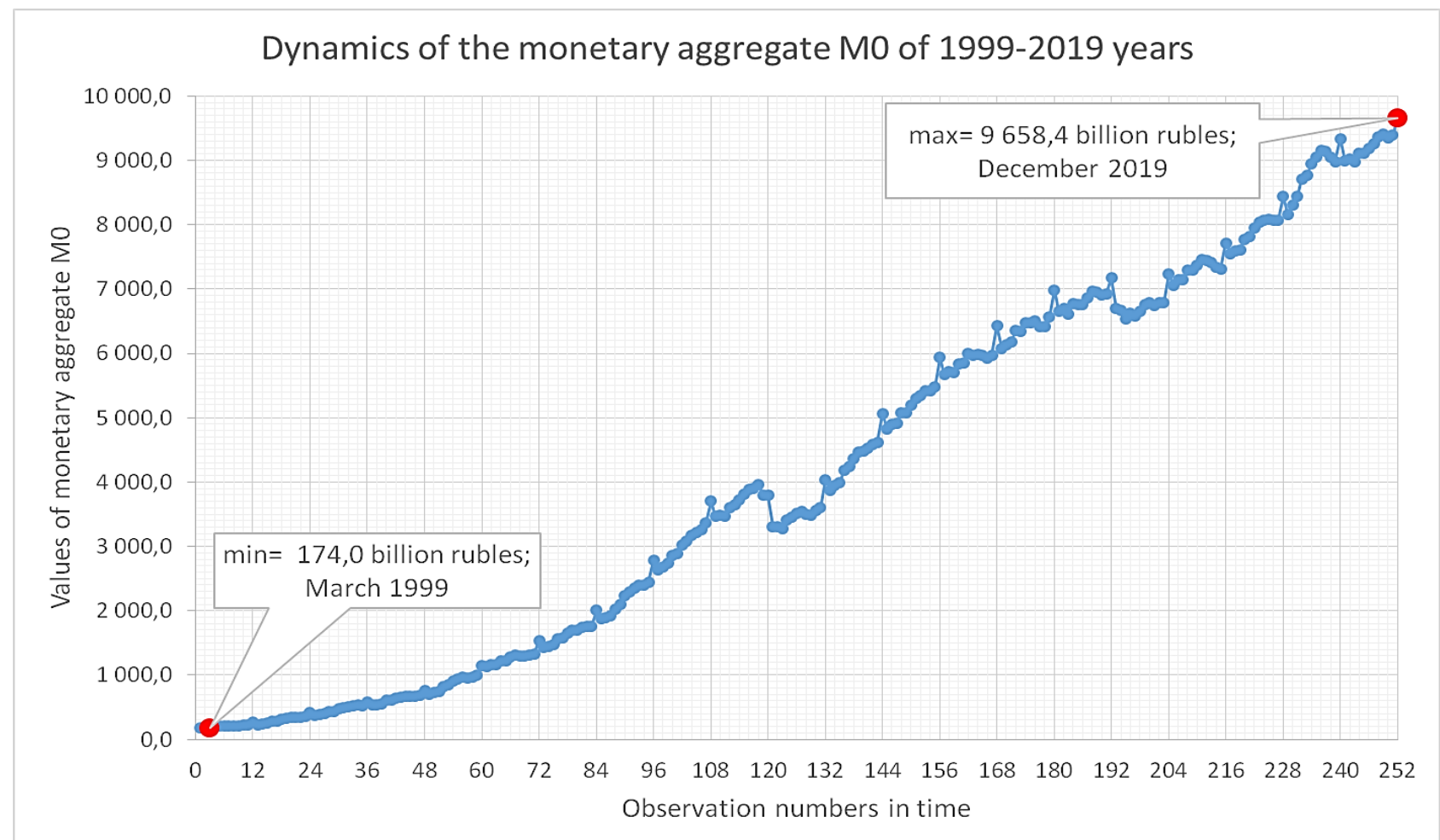

Fig.1 Dynamics of the monetary aggregate M0 of 1999-2019 years in Russia

Source: author's research using open statistical data Central Bank of the Russian Federation, crb.ru

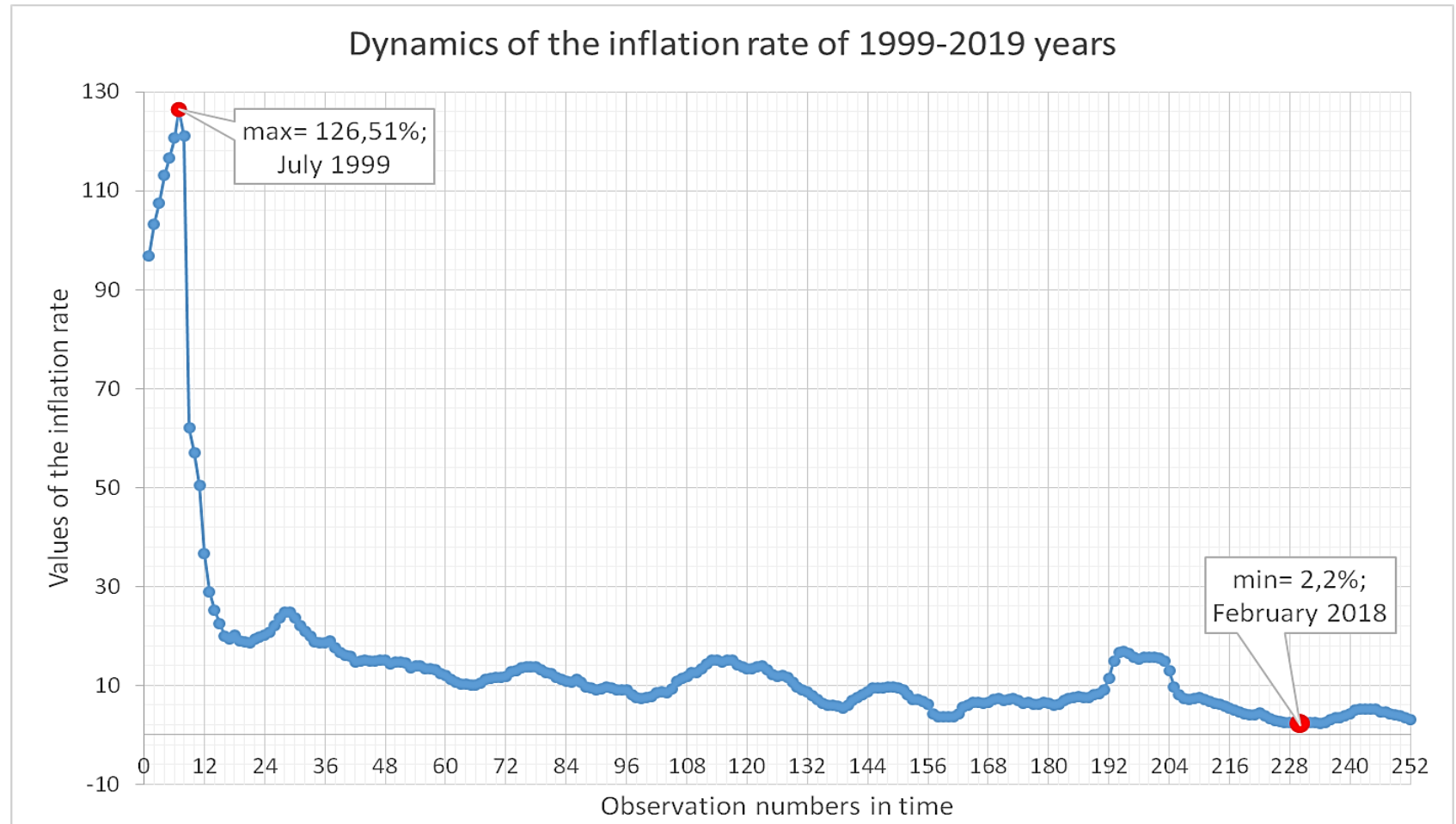

Fig.2 Dynamics of the inflation rate of 1999-2019 years in Russia

Source: author's research using open statistical data of Federal State Statistics Service of the Ministry of Economic Development of the Russian Federation (Rosstat) gks.ru 


\subsection{Model specification and identification}

The visual graphical analysis of statistical data on the annual dynamics of the inflation rate over the 20year period from 2000 to 2019 showed, that the behaviour of the inflation rate in various years differs from each other. In some years (for example, 2018, 2014, 2010, 2007, 2004, etc.) the inflation increased at the end of the year compared to the beginning of the year. But in some other years (for example, 2019, $2017,2016,2015,2011,2009,2008$, etc.) the opposite happened: inflation decreased by the end of the year compared with the beginning of the year. In the same way, the intra-annual behaviour of the inflation rate differs by month and year. Thus, changes of the inflation rate values do not depend on months or seasons. (See Figure 3).

As a result, in the course of the comparative analysis the time series of the Inf variable, it was found that the intra-annual dynamics of the inflation rate in Russia is different for different years. Neither a general trend during a year, nor a general pronounced seasonal component for all the years under consideration were revealed.

Therefore, being guided by the reasonable principle of economy and estimation accuracy of the model [16], the model lag value $k=1$ was taken for all independent variables.

Let us construct a field of correlation between the values of the monetary aggregate M0 in period $t$ and the values of the inflation rate Inf of the previous period $(t-1)$ according to the sample data (See Figure 4).

A visual analysis of the correlation field showed that the relationship between $M O_{t}$ and the inflation rate $\operatorname{Inf}\left(f_{t-1)}\right.$ is quite close and strong; its direction is opposite and decreasing; the form is nonlinear. Judging by the shape of the graph, there is reason to believe that the most probable assumptions about the shape of this nonlinear dependence are as follows: it is power-law, exponential, or hyperbolic.

Comparative analysis of the constructed pairwise nonlinear regressions showed that all three regressions are statistically significant (F-test, $t-$ statistics and their p-levels), confirm the influence of the inflation rate $\operatorname{Inf}(t-1)$ on $M 0_{t}$, and its nonlinear nature.

However, the quality of the power-law dependence is significantly higher than that of the hyperbolic and exponential ones (see Table 1).

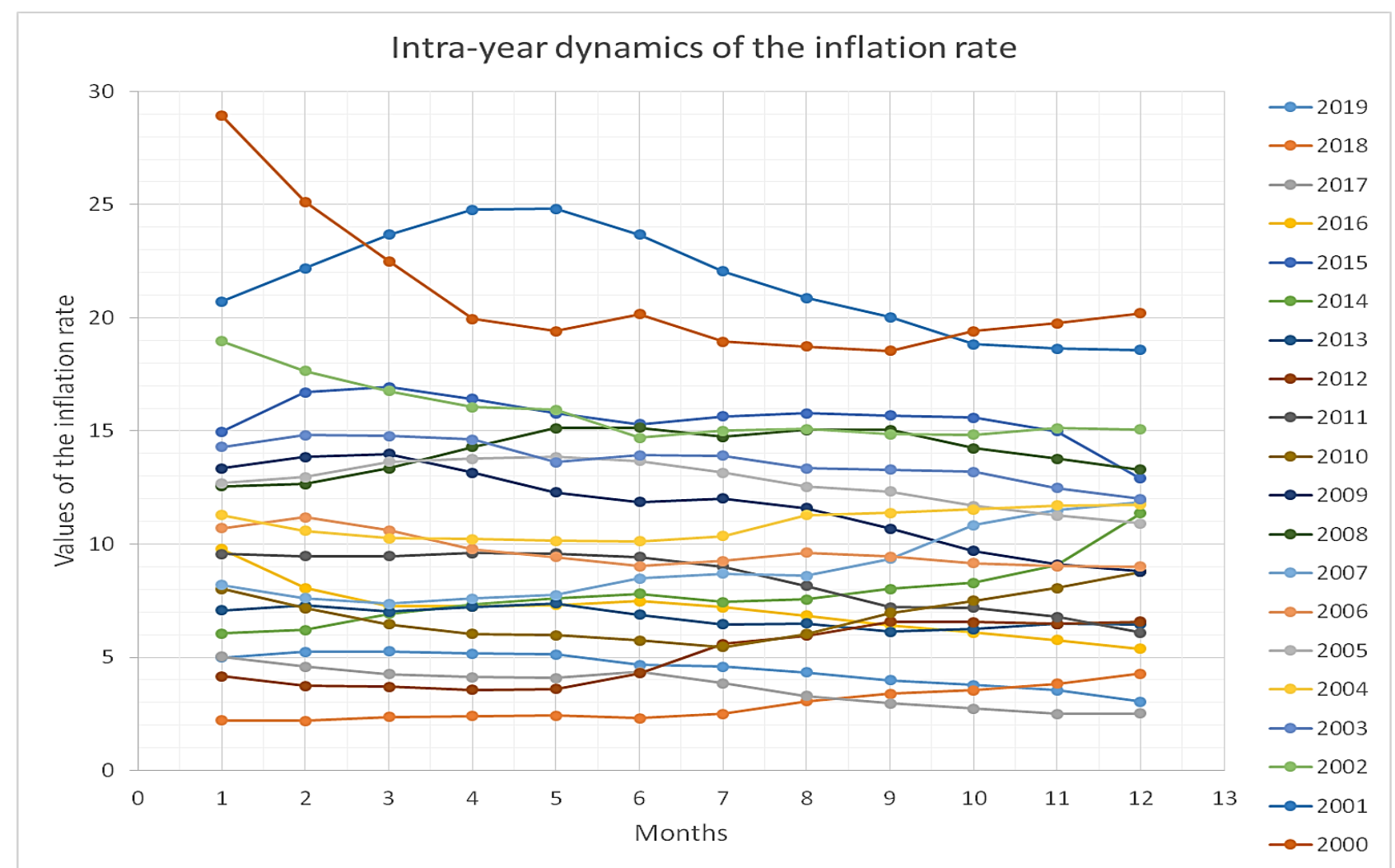

Fig.3 Intra-annual dynamics of the inflation rate in Russia

Source: author's research using open statistical data of Federal State Statistics Service of the Ministry of Economic Development of the Russian Federation (Rosstat) gks.ru 


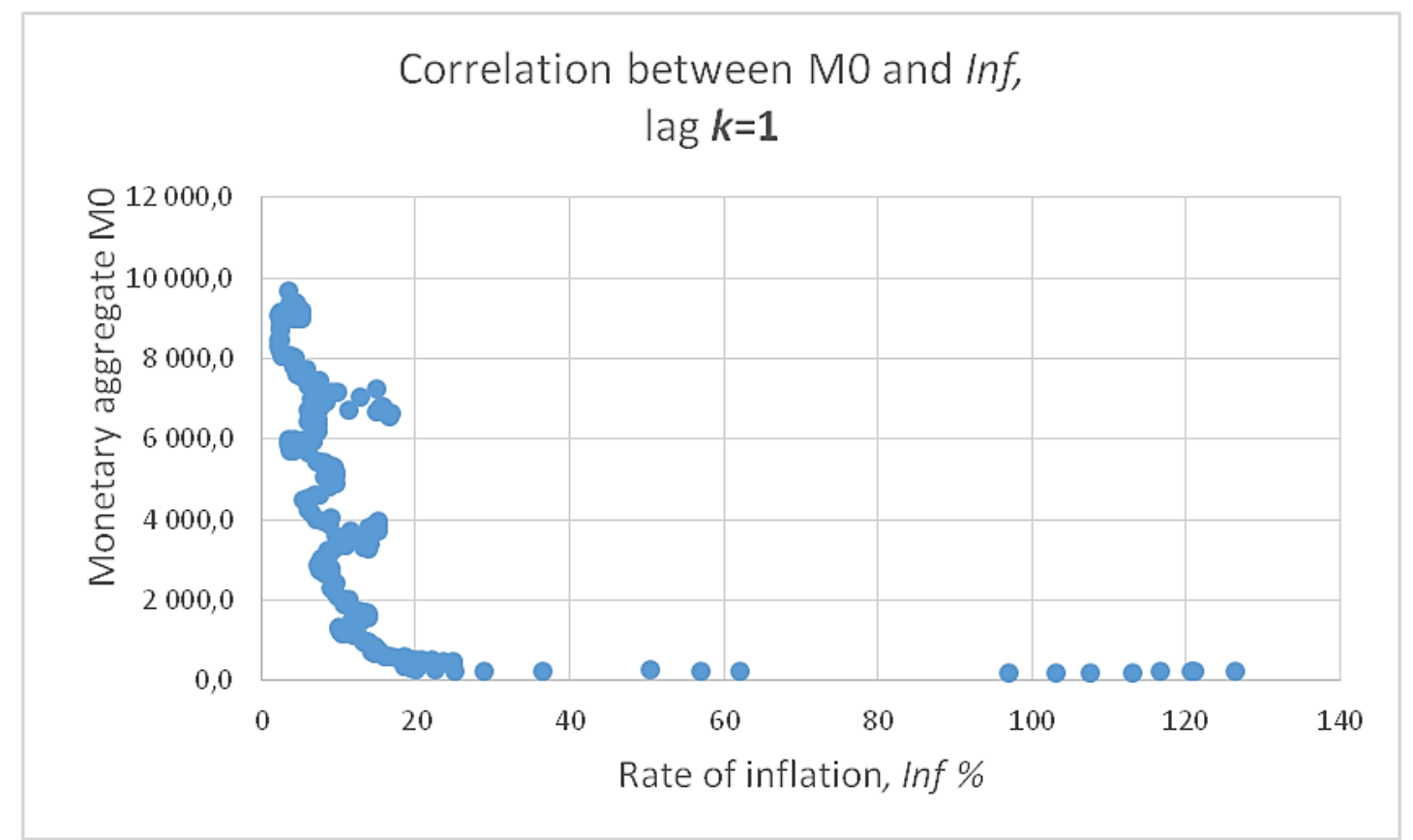

Fig.4 Correlation field between $\mathrm{M} 0$ and inflation rate with a time lag $k=1$

Source: author's research using open statistical data of Federal State Statistics Service of the Ministry of Economic Development of the Russian Federation (Rosstat) gks.ru

Table 1. Comparison of the paired regression relationship between $M 0_{t}$ and the inflation rate $\operatorname{Inf}(t-l)$

\begin{tabular}{l|c|c|c|c|c|c|c|} 
& Resulting equation & \multirow{2}{*}{$\mathrm{R}^{2}$} & F-test & \multicolumn{2}{|c|}{$\mathrm{t}$-statistic } & \multicolumn{2}{|c|}{$\mathrm{p}$-level } \\
\cline { 5 - 8 } & $M 0_{t}=49965 \cdot \operatorname{Inf} f_{(t-1)}^{-1,271}$ & 0,68 & 518,6 & 79,9 & 22,8 & $\approx 0$ & $\approx 0$ \\
\hline $\begin{array}{l}\text { Power-law } \\
\text { regression }\end{array}$ & $M 0_{t}=996,29+\frac{25193}{\operatorname{Inf} f_{(t-1)}}$ & 0,56 & 319,2 & 4,6 & 17,9 & $\approx 0$ & $\approx 0$ \\
\hline $\begin{array}{l}\text { Hyperbolic } \\
\text { regression }\end{array}$ & $M 0_{t}=4530,8 \cdot e^{-0,037 \cdot \operatorname{Inf}(t-1)}$ & 0,41 & 174,3 & 122,5 & 13,2 & $\approx 0$ & $\approx 0$ \\
\hline $\begin{array}{l}\text { Exponential } \\
\text { regression }\end{array}$ & & & & & & \\
\hline
\end{tabular}

Source: author's research

Power-law regression has the highest values of the determination coefficient $\mathrm{R}^{2}$, Fisher's F- test and $\mathrm{t}$ statistics of the regression coefficient at the variable $\operatorname{Inf}(t-1)$.

Thus, the influence of the inflation rate on the monetary aggregate $\mathrm{M} 0$ should be included in the model in the form of a power function.

Next, we consider the autoregression of M0.

Let us construct a field of correlation between the values of the monetary aggregate M0 in the period $t$ and its values of the previous period $(t-1)$ according to the sample data (see Figure 5).
A visual analysis of the correlation field showed that the relationship between $M 0_{t}$ and $M 0_{(t-1)}$ is very close and strong; its direction is positive and increasing; the shape is linear. This means that the influence of the variable $M 0_{(t-1)}$ should be taken into account in the model as a linear function.

So, the specification of the model based on the sample data was defined as an additive model:

$$
M 0_{t}=\alpha_{0}+\alpha_{1} \cdot \operatorname{Inf} f_{(t-1)}^{\beta}+\alpha_{2} \cdot M 0_{(t-1)}
$$

Where $\alpha_{0}, \alpha_{1}, \alpha_{2}, \beta$ are model parameters. 


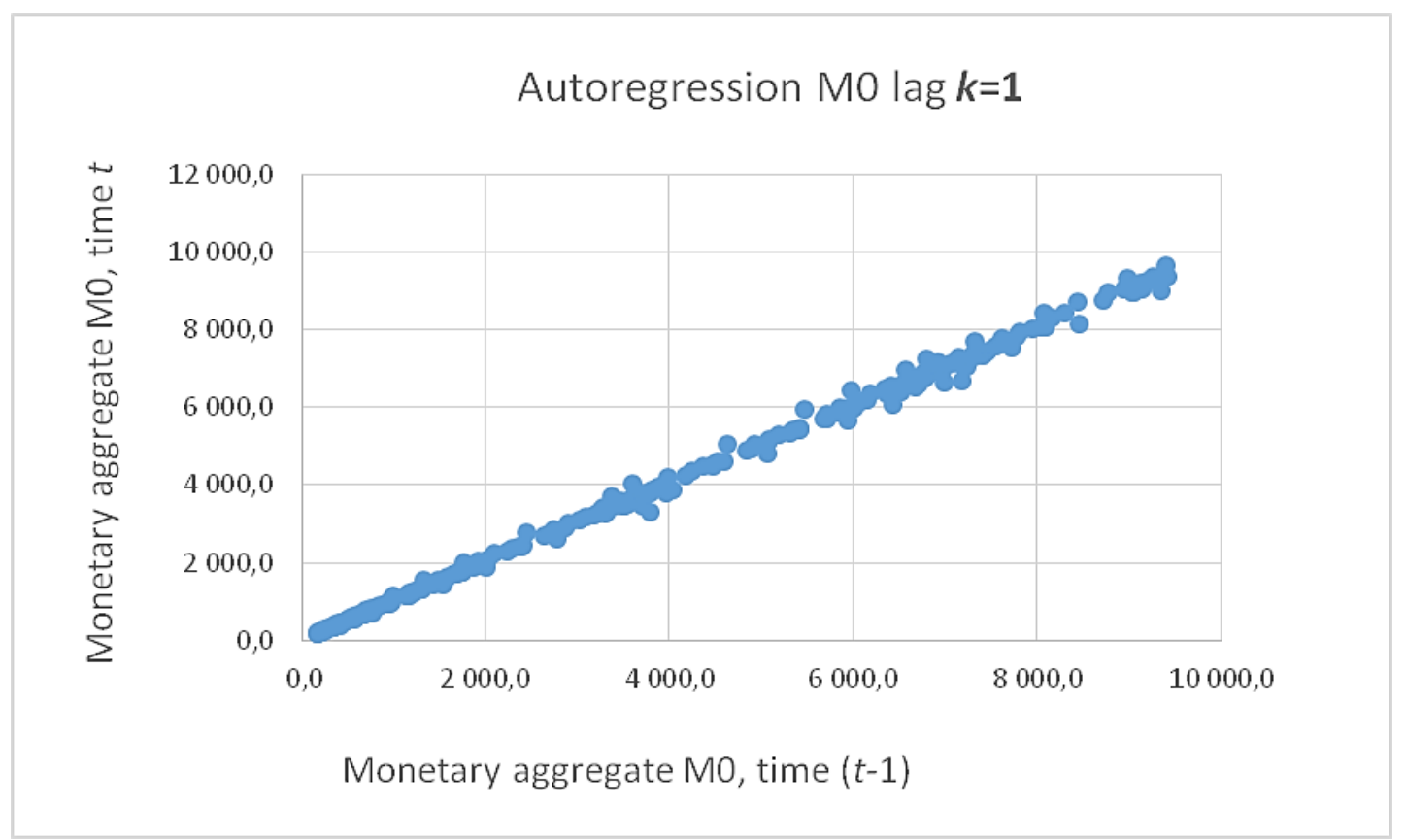

Fig.5 Autoregression M0 with the time lag $k=1$

Source: author's research using open statistical data of Central Bank of the Russian Federation crb.ru

However, this model has identification problems. Firstly, the number of estimated parameters is 4 , which is more than the number of equations in the system of normal equations using the least squares method. Secondly, this model cannot be linearized, i.e. select such a transformation to reduce it to linear multiple regression.

Therefore, in order to identify the model, a combined approach was used based on the iteration method and the least squares method.

The essence of this approach was as follows. First, the degree $\beta$ value should be estimated using the iteration method.

Then, we should enter an auxiliary variable:

$$
z=\operatorname{Inf} f_{(t-1)}^{\beta}
$$

After that, the model can be brought to the form of linear multiple regression and the other three parameters $\alpha_{0}, \alpha_{1}, \alpha_{2}$ can be estimated using the conventional least squares method.

The value of this exponent from the paired power regression was taken as the starting point for iterations of the exponent $\beta$ of the variable $\operatorname{Inf} f_{(t-1)}$ : $\beta=-1.271$. The iterations were chosen within the interval $[-3 ;-0.1]$ with the step 0.01 .

Estimated parameters $\alpha_{0}, \alpha_{1}, \alpha_{2}$ and the quality of the resulting models were estimated at each iteration step using the least squares method. The main quality criteria of the resulting models were the adjusted coefficient of determination $\mathrm{R}^{2}$, Fisher's F-test, $\mathrm{t}$ - statistics, approximation errors, the accuracy of the obtained forecasts, etc.

The resulting set of models was divided into 2 subsets. One subset contained models that had unsatisfactory estimates of one or more parameters $\alpha_{i}$, because their level of significance exceeded the threshold level of $5 \%$ ( $p$-level $\geq 0.05$ ). Such models were excluded from further consideration.

Another subset of the obtained models had good quality: the high value of the adjusted coefficient of determination $\left(R^{2} \geq 0.05\right)$, Fischer's F-test $(\mathrm{F} \geq 205000$ with $p$-level $=0)$, and $t$-statistics of parameters $\alpha_{I}(t$-statistics $\geq 2$ with $p$-level $\leq 0.03)$, as well as a good approximation to the actual data (less than $3.1 \%$ ). Among these models, the optimal one was chosen. All other things being equal, the decisive factor was the forecasting accuracy.

Thus, the optimal model from the subset of evaluated models of good quality has the following form:

$$
\begin{array}{ccc}
M 0_{t}=368,5 \cdot \operatorname{Inf} f_{(t-1)}^{-1,3}+ & 1,001 \cdot M 0_{(t-1)} \\
t \text {-staistic } & 2,255 & 310,147 \\
p \text {-level } & 0,025 & 0
\end{array}
$$

The values of $t$-statistics and their $p$-level, the high value of the Fisher's F-test equal to 205795.46 ( $p$-level is 0 ), and the adjusted coefficient of determination $\mathrm{R}^{2}=0.995$ indicate a high quality, statistical significance and adequacy of the model. The model is suitable for use. 


\section{Discussion of the results}

\subsection{Estimation of the forecasting power of the model}

The calculation of the average approximation errors indicates a very good fit of the model and the closeness of the results to the actual data.

$$
\begin{gathered}
A=\frac{100 \%}{n} \cdot \sum_{i=1}^{n}\left|\frac{e_{i}}{M 0_{t, i}}\right|=2,47 \% \\
V=\frac{100 \%}{\overline{M 0}} \cdot \sqrt{\sum_{i=1}^{n} \frac{e_{i}^{2}}{n}}=3,02 \%
\end{gathered}
$$

Where $n$-sample size; it is equal to 251 ; $e_{i}$ - model margins; deviations of simulated values from actual ones;

$M 0_{t, i}$ - actual values of the monetary aggregate M0 for the $i$-th observation in the sample;

$\overline{M 0}$ - the average value of the monetary aggregate $\mathrm{M} 0$ for the sample.

Thus, we have found that the simulated values of the monetary aggregate $\mathrm{M} 0$ deviate from the actual data by $3 \%$ on average, which did not exceed the target threshold of $5 \%$.

Individual relative deviations of the simulated values of the monetary aggregate $\mathrm{M} 0$ from its actual values for the sample for the period under review range from $0.019 \%$ to $16.85 \%$. That does not exceed the acceptable level of forecast error, taken equal to 20\%. [13].

Thus, the model has high forecasting accuracy. (See Figure 6).

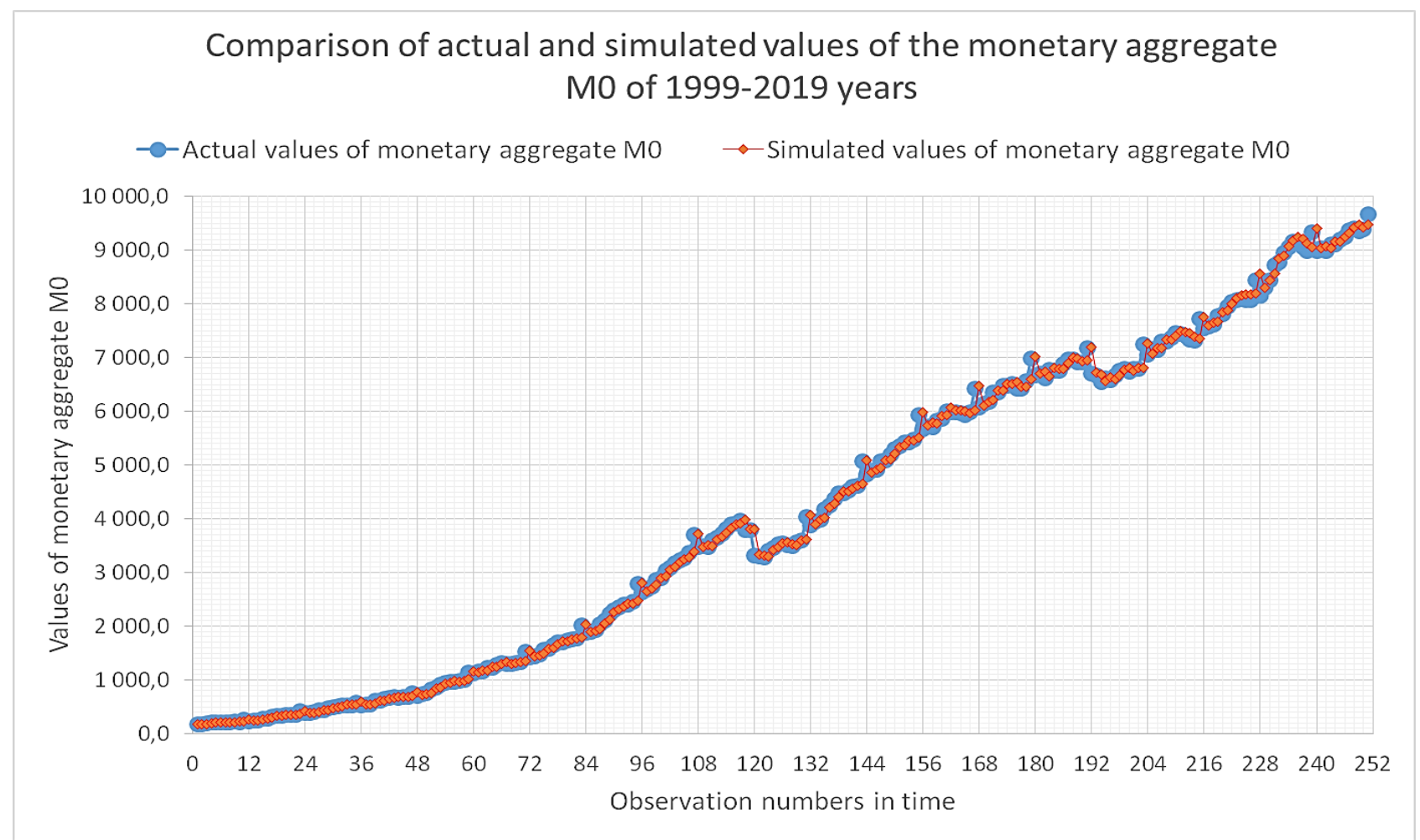

Fig.6 Comparison of the actual and simulated values of the monetary aggregate M0 of 1999-2019 years. Source: author's research.

\subsection{Approbation of the model}

Let's test the model by calculating the forecast values of the monetary aggregate $\mathrm{M} 0$ for 7 months of the current 2020 (from January to July, inclusively) and compare them with the actual values of M0 that this monetary aggregate took in this period (see Table 2 , columns 3 and 4 , respectively).
The obtained forecast values for the current months are very close to actual data (see Figure 7). Almost all individual deviations, with the exception of one, did not exceed the target threshold of 5\% (see Table 2, column 5).

As it follows from the presented results, the model is highly accurate and adequately reflects the value of the monetary aggregate $\mathrm{M} 0$ in the forecast period. 
Table 2 Forecast of the monetary aggregate M0 for January 2020 - July 2020

\begin{tabular}{|c|c|c|c|c|}
\hline $\begin{array}{l}\text { The inflation rate } \\
\text { value in the period } \\
(t-1), \operatorname{Inf} f_{(t-1)}, \%\end{array}$ & $\begin{array}{l}\text { The monetary } \\
\text { aggregate } \mathrm{M} 0 \text { value } \\
\text { in the period }(t-1) \text {, } \\
M 0_{(t-1)}, \text { bln. roubles }\end{array}$ & $\begin{array}{c}\text { Forecast of the } \\
\text { monetary } \\
\text { aggregate } \mathrm{M} 0 \text { for } \\
\text { the period } t, M 0_{t}, \\
\text { bln. roubles }\end{array}$ & $\begin{array}{l}\text { The actual value of } \\
\text { the } \mathrm{M} 0 \text { in the } \\
\text { period } t \\
M 0_{t, \text { act }} \text {, bln. roubles }\end{array}$ & $\begin{array}{c}\text { Relative deviation } \\
\text { of forecasted } \\
\text { values from the } \\
\text { actual ones, \% }\end{array}$ \\
\hline 1 & 2 & 3 & 4 & 5 \\
\hline $\begin{array}{c}3.05 \% \\
\text { December } 2019\end{array}$ & $\begin{array}{c}9658.4 \\
\text { December } 2019\end{array}$ & $\begin{array}{c}\mathbf{9 7 5 0 . 2 6} \\
\text { January } 2020\end{array}$ & $\begin{array}{c}9489.0 \\
\text { January } 2020\end{array}$ & $2,75 \%$ \\
\hline $\begin{array}{c}2.42 \% \\
\text { January } 2020\end{array}$ & $\begin{array}{c}9489.0 \\
\text { January } 2020\end{array}$ & $\begin{array}{c}\mathbf{9 6 1 1 . 0 3} \\
\text { February 2020 }\end{array}$ & $\begin{array}{c}9670.8 \\
\text { February } 2020 \\
\end{array}$ & $-0,62 \%$ \\
\hline $\begin{array}{c}2.31 \% \\
\text { February } 2020\end{array}$ & $\begin{array}{c}9670.8 \\
\text { February } 2020\end{array}$ & $\begin{array}{c}\mathbf{9 8 0 0 . 2 0} \\
\text { March } 2020\end{array}$ & $\begin{array}{c}10241.0 \\
\text { March } 2020\end{array}$ & $-4,30 \%$ \\
\hline $\begin{array}{c}2.55 \% \\
\text { March 2020 }\end{array}$ & $\begin{array}{c}10241.0 \\
\text { March } 2020\end{array}$ & $\begin{array}{c}10355.81 \\
\text { April } 2020\end{array}$ & $\begin{array}{c}10912,0 \\
\text { April } 2020\end{array}$ & $-5,10 \%$ \\
\hline $\begin{array}{c}3.10 \% \\
\text { April } 2020\end{array}$ & $\begin{array}{c}10912.0 \\
\text { April } 2020\end{array}$ & $\begin{array}{l}11002.78 \\
\text { May } 2020\end{array}$ & $\begin{array}{c}11209,3 \\
\text { May 2020 }\end{array}$ & $-1,84 \%$ \\
\hline $\begin{array}{c}3.03 \% \\
\text { May 2020 }\end{array}$ & $\begin{array}{c}11209.3 \\
\text { May } 2020\end{array}$ & $\begin{array}{l}\mathbf{1 1} \mathbf{3 0 2 . 8 0} \\
\text { June } 2020\end{array}$ & $\begin{array}{c}11516,4 \\
\text { June } 2020\end{array}$ & $-1,85 \%$ \\
\hline $\begin{array}{c}3.21 \% \\
\text { June } 2020\end{array}$ & $\begin{array}{c}11516.4 \\
\text { June } 2020\end{array}$ & $\begin{array}{l}\mathbf{1 1} \mathbf{6 0 3 . 7 9} \\
\text { July } 2020\end{array}$ & $\begin{array}{l}11817.8 \\
\text { July } 2020\end{array}$ & $-1,81 \%$ \\
\hline
\end{tabular}

Source: author's research

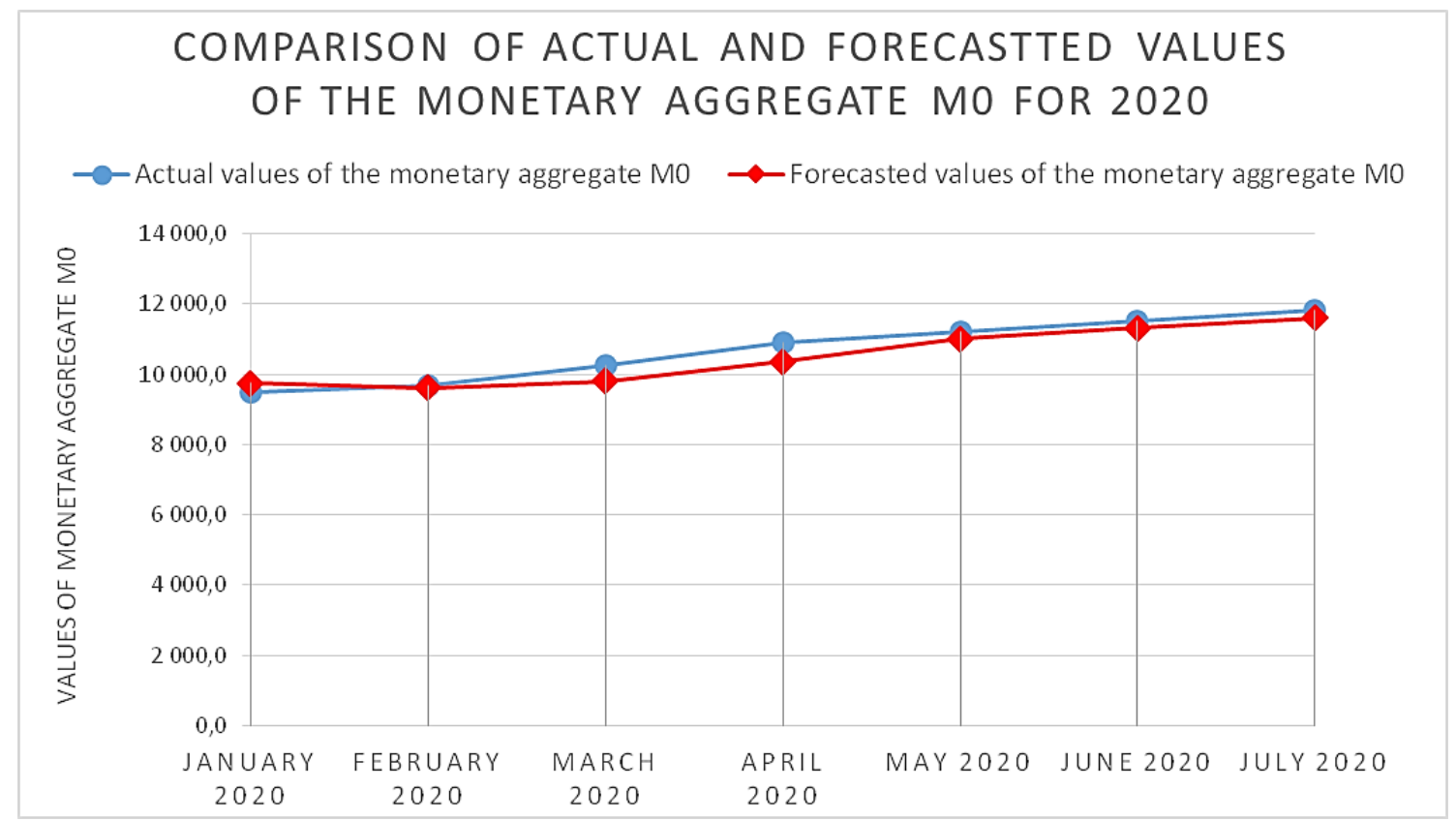

Fig.7 Comparison of the actual and forecasted values of the monetary aggregate M0 for 2020 year.

Source: author's research.

It can be concluded that the main purpose and objectives of this research have been achieved. There has been obtained the model that is suitable for the rapid estimation of the monetary aggregate $\mathrm{M} 0$. It has a fairly high forecasting power (the average error of selection by the model is 3\%). At the same time, the model is quite suitable for practical use; it is not overloaded with many variables and is available for application. 


\section{Conclusion}

The optimal ratio of the high quality of the resulting model, its forecasting power, simplicity and ease of use allows obtaining very accurate operational estimates of the monetary aggregate M0 value.

The actual forecasting of M0 value and the possibility of easy adjustment of its values in a changing economic situation provide an opportunity for the state and various players in the financial market to quickly estimate the amount of cash held by the population, organizations, entrepreneurs, etc. in the form of hard cash (banknotes, coins) with quick liquidity both at the current moment, and in subsequent periods of time.

This, in turn, allows solving problems that are of interest in terms of possible investment. In particular, the model enables forecasting and estimating the amount of funds that can potentially be used for investments, bank deposits, stocks, bonds, etc. [1].

Forecasting the value of the monetary aggregate M0 can also find its application in the fiscal policy [2].

Further, if we take into account the monetary methods for estimating the shadow activity in the country, based on the hypothesis that cash is mainly used in shadow calculations, then the forecast of the M0 aggregate can also be useful to tax authorities in estimating the amount of shadow income and shortfall in tax revenues of the budget.

\section{Declaration of interest}

Author declares that there is no Conflict of Interest.

\section{References:}

[1] Adiguzel Mercangöz B. (Ed.). (2020). Handbook of Research on Emerging Theories, Models, and Applications of Financial Econometrics. Springer.

[2] Afonso A. and Sousa R.M. (2009). The macroeconomic effects of fiscal policy. Working paper no.991. European Central Bank.

[3] Aikaeli J. (2007). Money and inflation dynamics: A lag between change in money stock and the corresponding inflation response in Tanzania. Working papers series. SSRNid1021227.

[4] Baltagi B. H. (2015). Solutions Manual for Econometrics. Springer.
[5] Banerji A. (2002). Money Demand, Russian Federation: Selected Issues and Statistical Appendix, IMF Staff Country Report No.02/75. Washington: International Monetary Fund.

[6] Batova M. (2020). Modelling the amount of cash in circulation in a country using linear multiple regression, Journal of Physics: Conference Series, Volume 1564, International Conference on Mathematical Models \& Computational Techniques in Science \& Engineering 22-24 February 2020, London, UK, https://iopscience.iop.org/article/10.1088/17426596/1564/1/012031/pdf.

[7] Batova M. (2020), Cash in circulation in Russia, Mendeley Data, V1, doi: http://dx.doi.org/10.17632/hchknjswvh.1.

[8] Bozhechkova A., Petrova D., SinelnikovaMuryleva E., Trunin P., Chentsov A. (2018). Building of monetary and currency markets models. Scientific papers № 175P, Moscow: Gaidar Institute of economic policy. (in Russian).

[9] Cipra, T. (2020). Time Series in Economics and Finance. Heidelberg: Springer.

[10] Choudhry T. (1998). Another visit to the Cagan model of money demand: the latest Russian experience, Journal of International Money and Finance, Vol.17. No.2, pp.355-376.

[11] Culberts M. J.(1960). Friedman on the lag in effect of monetary policy, Journal of Political Economy, Vol.68, No.6.

[12] Drobyshevsky S. et al. (2010). Modelling the demand for money in the Russian economy in 1999-2008, Moscow. (in Russian).

[13] Eliseeva I. I., Kurysheva S. V., Neradovskaya Yu. V., Belyakov D. I., Galiullina L. M. and Kabachek A.V. (2019). Econometrics: textbook for bachelor's and master's degrees. Moscow: Yurayt Publishing House. (in Russian).

[14] Friedman M. (1956). Studies in the quantity theory of money, University of Chicago Press.

[15] Hadjiantoni S. (2015). Numerical methods for the recursive estimation of large-scale linear econometric models. Theses of Dissertation Research. Queen Mary University of London.

[16] Kashyap R.L. and Rao A. R. (1976). Dynamic 
Stochastic Models from Empirical Data, Academic Press.

[17] Keynes D. M. (2002). General theory of employment, interest and money, Moscow: Helios APB. (in Russian).

[18] Keynes J.M. (1936). The General Theory of Employment, Interest and Money, New York: Macmillan Cambridge University Press.

[19] Korhonen I., Mehrotra A. (2007). Money demand in post-crisis Russia: De-dollarisation and re-monetisation, Bank of Finland, BOFIT Institute for Economies in Transition, Helsinki.

[20] Marshall A. (1929). Money, Credit and Commerce. London: Macmillan.

[21] Mills T. (2014). Analysing Economic Data. Heidelberg: Springer.

[22] Mukhamediev B. M., Bordousov O. V. (2003) Short course of lectures on econometrics, Almaty: Kazan University. (in Russian).

[23] Neusser K. (2016). Time Series Econometrics. Heidelberg: Springer.

[24] New economic dictionary / Edited by Azriliyan A.N. (2006). Moscow: Institute of new Economics. (in Russian).

[25] Özdemir D. (2016). Applied Statistics for Economics and Business. Springer.

[26] Pigou A.C. (1917). The value of money, The Quarterly Journal of Economics, Vol.32. No.1, pp.38-65.

[27] Ponomarenko A. (2016). Essays on monetary analysis in Russia. Economics and Finance. Université de Strasbourg.

[28] Savradym V., Gorbatko Ju. (2019). The structural and dynamic analysis of cash circulation in the Russian federation, Journal Siberian Financial School No.1(132), pp.95-98.

[29] Sinelnikova-Muryleva E. V. (2011). Innovations in the sphere of money payments and demand for money in Russia. Scientific papers №157P, Moscow: Gaidar Institute of economic policy. (in Russian).
[30] Soofi A. S. et al. Modelling and Forecasting Financial Data (2002). Soofi A. S. and Liangyue C. (Eds.). Heidelberg: Springer.

[31] Sosunov K. A. (2013). Estimation of the demand function for money in Russia, Journal of the new economic Association, Vol.18, No.2, pp.89-99. (in Russian).

[32] Victoria Said Ayubu (2013). Monetary Policy and Inflation Dynamics: An empirical case study of Tanzanian economy, UMEA Universitet.

[33] Vymyatnina Y. (2006). Monetary policy transmission and CBR monetary policy. In: Return to Growth in CIS Countries, Springer Berlin Heidelberg, pp.23-39.

\section{Creative Commons Attribution License 4.0 (Attribution 4.0 International, CC BY 4.0)}

This article is published under the terms of the Creative Commons Attribution License 4.0

https://creativecommons.org/licenses/by/4.0/deed.en US 